\title{
miscellany
}

\section{Mental Health Act Commission appointments}

The Mental Health Act Commission is responsible for the appointment of doctors to undertake second opinions under the powers of Part 5 of the Mental Health Act 1983. It invites consultant psychiatrists of at least 5 years standing to apply for appointment to its panel of available doctors. Details of the appointment and application forms are available from the Mental Health Act Commission, Maid Marion House, 56 Hounds Gate, Nottingham NG1 6BG (tel: 0115943 7147).

\section{forthcoming events}

The Andrew Sims Centre for Professional Development would like to announce the following events: Under Starter's Orders - A National Conference on the New Mental Health Act (28 November 2002, Leeds) - the draft Mental Health Bill proposes the most fundamental changes to mental health legislation since 1959; this conference will welcome an eminent group of national experts to explain the processes and present their analyses. Clinical Negligence 2 'You Are Required To Attend Court On ...' (2 December 2002, Leeds) is a course that aims to provide participants with the confidence, knowledge and skills to better equip themselves to face court proceedings and achieve a good outcome. Overcoming Depression Training Roadshow - Dr Chris Williams will present a tutorial introducing this form of treatment that uses the proven cognitivebehavioural therapy approach. The roadshow sessions will be held on 5 December 2002 in London; 16 January 2003 in Cardiff; 20 February 2003 in Manchester; and 20 March 2003 in Edinburgh. For further information, please contact the course administrator at The Andrew Sims Centre (tel: 0113305 6044; fax: 0113305
6041; e-mail: AndrewSimsCentre@ cwcom.net) or visit the website: http:// www.leedscommunityandmentalhealth trust.org/andrewsims.

\section{The British Neuropsychiatry} Association (BNPA) 2003 Annual Meeting will be held at the Institute of Child Health, central London on 13-14 February 2003. The meeting will cover the following topics: recovering from head injury, medico-legal aspects of neuropsychiatry and the neuropsychiatry of love (A feast for Valentine's day). The meeting includes keynote addresses from prominent international and UK speakers, along with a session for members' contributions. BNPA will also be holding a conference on 12 February 2003, sponsored by the Institute of Social Psychiatry, on Stepping out after Brain Injury. This will be linked to the BNPA conference session on recovering from head injury. For further information please contact Gwen Cutmore, BNPA Conference Secretary, Landbreach Boatyard, Chelmer Terrace, Maldon, Essex CM9 5HT (tel/fax: 01621 843334; e-mail: gwen.cutmore@ lineone.net; website: http://www.bnpa. fsnet.co.uk). For details of BNPA membership, open to medical practitioners in psychiatry, neurology and related clinical neurosciences, please contact: The Secretary, Professor A. S. David, Department of Psychological Medicine, Institute of Psychiatry, De Crespigny Park, Denmark Hill, London SE5 8AF.

St Bart's and Royal London Hospital Regional MRCPsych Course Parts I and II (second semester) a trail-blazing course that sets the standard for training for the new syllabus-based MRCPsych examination, will start in February 2003. Regular interview skills, critical appraisal and mock written exams are all included, as well as all clinical and basic science lectures. For further details please contact: Dr Nick Bass, Programme Director (tel: 0207377 7967; fax: 020 7377 7903; e-mail: nick.bass@elcmht. nhs.uk) or Mrs Dale Tillock, Course Administrator (tel: 0208880 6293/1; fax: 0208880 6250).

The 10th International Congress of the European Society for Dermatology and Psychiatry (ESDAP) will be held on 8-10 May 2003 in Brussels, Belgium. For further information, please e-mail: fpoot@ulb.ac.be. 